\section{UCDNN}

LIBRARY
University of Connecticut OpenCommons@UConn

Faculty Articles and Papers

School of Law

2013

\title{
The Promise and Perils of Renewable Energy on Tribal Lands
}

Sara Bronin

University of Connecticut School of Law

Follow this and additional works at: https://opencommons.uconn.edu/law_papers

Part of the Energy and Utilities Law Commons, and the Indian and Aboriginal Law Commons

\section{Recommended Citation}

Bronin, Sara, "The Promise and Perils of Renewable Energy on Tribal Lands" (2013). Faculty Articles and Papers. 148. https://opencommons.uconn.edu/law_papers/148 


\section{HEINONLINE}

Citation: 26 Tul. Envtl. L.J. 221 2012-2013

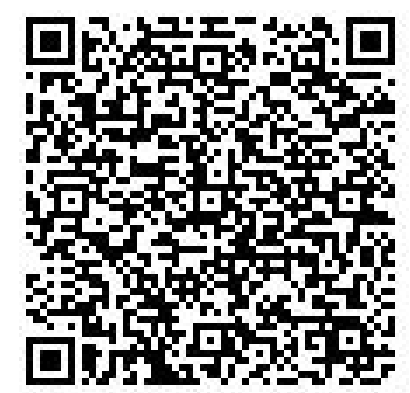

Content downloaded/printed from

HeinOnline (http://heinonline.org)

Mon Aug 15 16:47:44 2016

-- Your use of this HeinOnline PDF indicates your acceptance of HeinOnline's Terms and Conditions of the license agreement available at http://heinonline.org/HOL/License

-- The search text of this PDF is generated from uncorrected OCR text.

-- To obtain permission to use this article beyond the scope of your HeinOnline license, please use:

https://www.copyright.com/ccc/basicSearch.do?

\&operation $=$ go\&search $\mathrm{Type}=0$

\&lastSearch $=$ simple\&all=on\&titleOrStdNo=1047-6857 


\title{
The Promise and Perils of Renewable Energy on Tribal Lands*
}

\author{
Sara C. Bronin ${ }^{\dagger}$
}

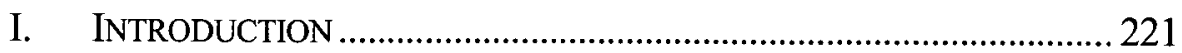

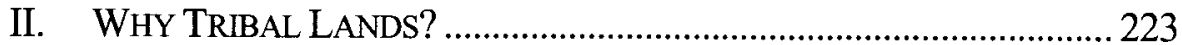

III. THE UNFULFILLED PROMISE OF ITEDSA ........................................ 229

IV. REMAINING CHALLENGES IN DEVELOPING RENEWABLE

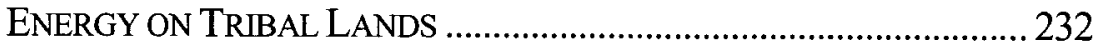

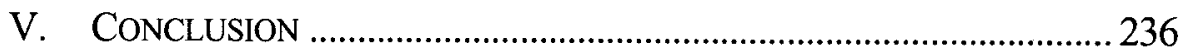

\section{INTRODUCTION}

In theory, the ninety-five million acres of tribal lands ${ }^{1}$ in the United States are perfect sites for the renewable energy infrastructure that could help to meet the energy needs of not just tribes, but the rest of the nation.

* (C) 2013 Sara C. Bronin. This Article is a republication with minor editorial changes reprinted with permission of the publisher from The Promise and Perils of Renewable Energy on Tribal Lands, in TRIBES, LAND, AND THE ENVIRONMENT 126-44 (Sarah Krakoff \& Ezra Rosser eds., 2012).

$\dagger$ Associate Professor and Program Director of the Center for Energy \& Environmental Law, University of Connecticut School of Law.

1. In this Article, the term "tribal lands" is meant to be consistent with that definition in the Indian Tribal Energy Development and Self-Determination Act (ITEDSA) and includes "any land or interests in land owned by any Indian tribe, title to which is held in trust by the United States, or is subject to a restriction against alienation under laws of the United States." 25 U.S.C. $\S 3501(12)$ (2006). It is not intended to encompass all of those lands defined in ITEDSA as "Indian lands," which include:

(A) any land located within the boundaries of an Indian reservation, pueblo, or rancheria;

(B) any land not located within the boundaries of an Indian reservation, pueblo, or rancheria, the title to which is held-

(i) in trust by the United States for the benefit of an Indian tribe or an individual Indian;

(ii) by an Indian tribe or an individual Indian, subject to restriction against alienation under laws of the United States; or

(iii) by a dependent Indian community; and

(C) land that is owned by an Indian tribe and was conveyed by the United States to a Native Corporation pursuant to the Alaska Native Claims Settlement Act (43

U.S.C. 1601 et seq.), or that was conveyed by the United States to a Native Corporation in exchange for such land.

Id. § 3501(2). The term "Indian lands" includes land that is owned by or in trust for individual Indians. 
They often have plentiful sunlight, wind, and open space, resources that are important prerequisites for renewable energy production. They are not necessarily governed by the land use or environmental regulations that sometimes inhibit energy projects in more densely populated areas. At the same time, on-site renewable energy may provide direct economic benefits for tribes, including "green jobs," infrastructure improvements, and production revenues shared by the community. Moreover, on-site generation could significantly reduce energy expenses for tribal households, who pay more for energy than any other group in the country. $^{2}$

In keeping with this theory, the Indian Tribal Energy Development and Self-Determination Act (ITEDSA) was passed in 2005 to provide tribes with a framework for developing renewable energy infrastructure. ${ }^{3}$ It aims to allow tribes to regulate the conveyance of their own energy resources, giving them, under certain circumstances, the ability to enter into leases and other agreements for the construction of renewable energy networks without federal supervision. ${ }^{4}$ Despite its expansive aims, ITEDSA is flawed in two significant ways. First, as written, ITEDSA fails to correct for misplaced financial incentives for renewable energy development by tribes. The law continues federal policies that ensure that non-Indians ${ }^{5}$ and nontribal business entities often reap far greater economic rewards than tribes or members of tribes.

Second, ITEDSA, if fully implemented, has the potential to increase the incidence of energy sprawl - that is, the occupation of vast, extraurban or rural tracts of land by energy generation facilities. The negative effects of energy sprawl created by large-scale renewable facilities are well documented. ${ }^{6}$ To the extent that the renewable energy networks are used to serve tribal lands, it is important to encourage tribes to assess environmental and ecological impacts carefully. To the extent that transmission or distribution lines connected to facilities located on tribal lands extend beyond tribal lands, ITEDSA or some other statute must articulate how tribal members can or should influence such lines' siting.

2. U.S. ENERGy Info. Admin., ENERgy CONSUMPTION and RENEWABle ENERgy DEvelopmENT POTENTIAL ON INDIAN LANDS 3-10 (2000), available at ftp://ftp.eia.doe.gov/pub/ pdf/renewables/ilands.pdf.

3. 25 U.S.C. $\S 3502$.

4. Id. $\S 3504$.

5. In this Article, the term "non-Indians" is meant to include all those individuals who are neither members of a Native American or Native Alaskan tribe nor a member of the relevant tribe. With respect to the latter group, one example is a Native American living within the boundaries of a reservation who is not a member of the tribe that regulates that reservation.

6. See Sara C. Bronin, Curbing Energy Sprawl with Microgrids, 43 CoNN. L. REV. 547 (2010). 
This Article analyzes the rationale for and substance of ITEDSAthe most significant federal law relating to renewable energy on tribal lands - and identifies ongoing challenges in the way the United States approaches renewable energy infrastructure siting on tribal lands. It does not offer a comprehensive set of solutions but rather identifies current issues in this area of law with a particular focus on the characteristics of tribal lands themselves.

\section{WhY TRIBAL LANDS?}

Tribal lands present a unique, and in many respects highly appealing, opportunity for the siting of renewable energy infrastructure. Renewable energy comes in many forms and includes any type of energy production that does not draw on finite resources. The National Renewable Energy Laboratory (NREL), a. United States Department of Energy research and development facility that focuses exclusively on researching renewable energy, has identified seven basic sources of renewable energy: biomass, hydropower, wind, geothermal, solar, hydrogen, and ocean. ${ }^{7}$ Of these seven sources, biomass (derived from organic matter, such as food crops, plants, algae, and waste products and gasses), and hydropower (derived from the kinetic energy of flowing water) are the most common. ${ }^{8}$ Wind (derived from the kinetic energy of wind and process primarily by turbines or windmills), geothermal (derived from the internal heat of the earth), and solar (derived from the conversion of sunlight, whether through photovoltaic or thermal means) are less common but seem to have captured greater attention from policymakers. ${ }^{9}$ Technical experts are still struggling to make hydrogen and ocean energy commercially feasible, so these energy resources will not be considered further by this Article. Currently in the United States, renewable energy comprises just $8 \%$ of energy consumed. ${ }^{10}$

Tribal lands, which are primarily located in the western United States, often have physical qualities highly conducive to the generation of renewable energy. The Department of Energy's Energy Information Administration (EIA) prepared a report in 2000 documenting these

7. Learning About Renewable Energy, NAT'L RENEwABlE ENERgy LAB. (Oct. 30, 2012), http://www.nrel.gov/learning/re_basics.html.

8. U.S. ENERGy INFO. AdMin., RENEWABLE ENERgy Consumption AND EleCtricity Preliminary StATISTICS 2009, at 1 fig.1 (2010), available at ftp://www.eia.gov/renewables/pre trends09.pdf.

9. See id.

10. Id. Nonrenewable resources including petroleum (37\%), natural gas (25\%), coal (21\%), and nuclear power (9\%) comprise the remaining $92 \%$. Id. 
qualities." It found that due to latitude or topographical conditions, many tribal lands would serve as good to excellent sites for hosting renewable energy infrastructure such as solar photovoltaics, concentrated solar power, wind generation, biomass, and geothermal wells. ${ }^{12}$ The EIA further identified tribal lands that would be best suited for central station development of electricity for renewable energy, and those that would be best suited for specific kinds of renewable energy. ${ }^{13}$ For example, the EIA found that biomass potential, which roughly corresponds to arable land, was promising in 118 of 298 reservations, which contain $56 \%$ of the tribal population studied by the EIA. ${ }^{14}$ With respect to geothermal resources (which can be directed toward electricity production, direct heating, or geothermal heat pumps), the EIA cross-referenced maps produced by NREL and determined that fifty-seven reservations may have potential for electricity production, with another seventy-two having potential for direct heat applications. ${ }^{15}$ Four years later, NREL conducted a survey that found that tribal lands had the potential for solar power equal to 4.5 times the then-current national energy generation. ${ }^{16}$ In addition, NREL found that the wind potential on tribal lands is about 535 billion kilowatt-hours per year, an amount that equals as much as $14 \%$ of the U.S. electric generation. ${ }^{17}$ All in all, the Bureau of Indian Affairs has estimated that tribal lands-which occupy just $5 \%$ of the land in this country-have $10 \%$ of all energy resources (both renewable and nonrenewable). ${ }^{18}$ Harnessing the renewable component of these

11. See U.S. ENERGY INFO. ADMIN., supra note 2.

12. See id. at 11-33. Assuming no significant topographical or boundary changes to the tribal lands analyzed by the EIA in 2000 , these assessments hold true today.

13. See id. at 23-31.

14. Id. at 29 (citing potential greater than five megawatts per county for these reservations).

15. Id. (noting that generally geothermal production is very site-specific and that these projections are estimates only).

16. Lizana K. Pierce, U.S. Dep't of Energy, DOEs Tribal Energy Program, HaRVESTING CLEAN ENERGY (2009), http://harvestcleanenergy.org/2010-conference-resources/2009-harvest ing-clean-energy-conference/2009-conference-presentations/lizanapierce-pdf/at_download/file

(PowerPoint presentation) (showing a map estimating generation "using [an] annual average solar resource from a tilt $=$ latitude collector" and finding total tribal solar generation potential at 17,606 billion kilowatt-hours per year, with total U.S. electric generation at 3853 billion kilowatthours per year).

17. Id. (estimating generation assuming five $\mathrm{MW} / \mathrm{km} 2$ of installed capacity, and capacity factors ranging from $25.1 \%$ (class 4 ) to $41.4 \%$ (class 7 )); see also OFFICE OF INDIAN ENERGY \& ECON. Dev., NATIVE AMERICAN WIND Resource ATLAS (2010) (cataloguing the potential for wind energy of twenty-nine reservations across the continental United States).

18. Lizana K. Pierce, U.S. Dep't of Energy, DOE's Tribal Energy Program, Office OF ENERGY EFFICIENCY \& RENEWABLE ENERGY (2010), http://appsl.eere.energy.gov/tribalenergy/ pdfs/2_doe_tep_overview_lkp.pdf(PowerPoint presentation). 
resources would help both tribes and the rest of the country reduce their dependence on fossil fuels.

Another characteristic that may make tribal lands more attractive for those building renewable energy projects is their relative absence of land use regulations, when compared to lands governed by nontribal government. Many state, county, and local governments have enacted rigorous land use regulations, including zoning ordinances, growth controls, aesthetic reviews, and environmental impact laws. ${ }^{19}$ The purpose of such regulations varies, but they primarily aim to control the way structures on real property look and are used. Public boards evaluate proposed projects for compliance with applicable regulations, and modifications may be required to accommodate certain requirements. ${ }^{20}$ On nontribal lands, particularly in urban areas, renewable energy projects can become delayed, modified, or canceled as land use regulations require. ${ }^{21}$ For example, a jurisdiction's zoning ordinance may include a height restriction that prohibits the installation of tall windmills that harness wind energy. ${ }^{22}$ Preservation laws might prevent the erection of solar panels on roofs or in vacant lots in historic districts. ${ }^{23}$ Environmental regulations may thwart the drilling of geothermal wells.

Such restrictions may not apply to renewable energy development on tribal lands. Tribal governments have sovereign authority over tribal lands and generally exercise jurisdiction with respect to these lands exclusive of state, county, or other local governments. ${ }^{24}$ Although some tribes have enacted zoning ordinances to regulate the way certain parcels are used, many tribes have not adopted land use regulations. ${ }^{25}$ Even where such regulations have been adopted, they may not be as effective as the same regulations on nontribal lands, due to limitations on tribal authority imposed by court decisions and federal statutes. ${ }^{26}$ And in

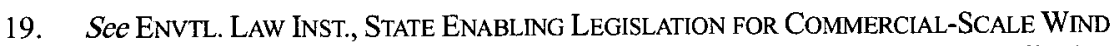
POWER SITING AND THE LOCAL GOVERNMENT ROLE (2011) (discussing state regulations affecting wind generation).

20. Id. at 5, 8-9, 29-35.

21. See id. at ii-iii.

22. Id. at 9 n.23.

23. See id. at 35 .

24. COHEN's HANDBOOK OF FEDERAL INDIAN LAW § 4.01(2)(c) (Nell Jessup Newton ed., 2005) [hereinafter COHEN's HANDBOOK].

25. Id. ("Many tribes are now beginning to impose land use and zoning controls similar to those adopted by non-Indian communities as a means of preserving and protecting resources." (citations omitted)).

26. Id. $\S 21.02(5)(\mathrm{b})$ (identifying both Brendale v. Confederated Tribes \& Bands of Yakima Indian Nation and the Indian Civil Rights Act as among the potential barriers to a fully effective and enforceable zoning regime). 
certain circumstances, land owned by a tribe may be subject to state, and not tribal, land use regulations. ${ }^{27}$

Moreover, tribes that have enacted land use regulations may be hindered in fully enforcing those regulations within reservation boundaries on non-Indian land-that is, real property within reservation boundaries that is not owned by Native American individuals or tribes. The existence of non-Indian "islands" within reservation boundaries derives largely from the Dawes General Allotment Act of $1887^{28}$ and companion laws and policies that carved up tribal lands into individual allotments, many of which become alienable to non-Indians, and also declared any remaining tribal lands to be "surplus," and alienable to nonIndians. Scholars have estimated that, until that practice was reversed in 1934 , almost 90 million acres of land was transferred to non-Indians. ${ }^{29}$ Today, conflicts involving tribal management of non-Indian lands within reservation boundaries endure, and the United States Supreme Court has been reluctant to allow tribes to regulate non-Indian activities. In an important 1981 case, United States v. Montana, the Court held that tribes may regulate non-Indians on non-Indian lands only if their "conduct threatens or has some direct effect on the political integrity, the economic security, or the health or welfare of the tribe. ${ }^{30}$ Applying Montana to the land use context (and contrary to at least one circuit court interpretation of Montana), ${ }^{31}$ a plurality of the Court wrote in Brendale $v$. Confederated Tribes \& Bands of Yakima Indian Nation that tribes should be able to impose land use regulations on only those areas within the reservation where tribal land predominated. ${ }^{32}$ The absence of a majority opinion in Brendale has created difficulties for tribes and nontribal governments attempting to reconcile conflicting land use regulations on the ground. With this unclear and unevenly enforced land use regulatory framework,

27. Such is the situation in the State of New York, according to two recent cases, with respect to lands relatively recently acquired by tribes. See Seneca-Cayuga Tribe of Okla. v. Town of Aurelius, 233 F.R.D. 278, 281 (N.D.N.Y. 2006); Cayuga Indian Nation of N.Y. v. Village of Union Springs, 390 F. Supp. 2d 203, 206 (N.D.N.Y. 2005).

28. 24 Stat. 388 (1887) (codified at 25 U.S.C. $\$ 331$ (2006)).

29. See COHEN's HANDBOOK, supra note $24, \S \S 1.01, .04$ ("In 1887, when the Dawes Act provided for allotting tribal lands to individual Indians, the American Indian's heritage in land totaled 138 million acres. Less than 50 years later, when the allotment policy was abandoned, only 48 million acres were left in Indian hands." (citations omitted)).

30. 450 U.S. 544,566 (1981).

31. See, e.g., Knight v. Shoshone \& Arapahoe Indian Tribes of the Wind River Reservation, Wyoming, 670 F.2d 900, 903 (10th Cir. 1982) (finding that the tribes involved in the litigation had a significant tribal interest in enacting a comprehensive land use regulation scheme within a reservation).

32. 492 U.S. 408,411 (1989). 
owners of renewable energy projects may find flexibility that they would not find on nontribal lands. ${ }^{33}$

Developers of renewable energy may be drawn to tribal lands for the foregoing reasons. Complementing this attractiveness to developers, Native American tribes have reason to want renewable energy production and distribution on tribal lands. Many tribes have cultures and religions rooted in concern for ecological balance, ${ }^{34}$ and renewable energy that is sensitive to environmental concerns, therefore, might be a fitting choice. More practically, there is the potential for revenue generation. Energy facilities' output may be harnessed by tribal governments and, in the right economic conditions, reduce operating costs spent on more traditional forms of energy procurement. Arrangements between third parties, such as leasing land or equipment, may generate other income for the tribe as a whole. And jobs may be created for individual members of tribes, related to installing, constructing, and maintaining solar panels, wind turbines, and other renewable technologies. ${ }^{35}$

Renewable energy development could also help meet the needs of the many underserved households on reservations that lack access to reliable, affordable energy, and in doing so advance the cause of "energy justice," the movement that, according to one scholar, "seeks to apply

33. Much has been written about the issues surrounding Montana and Brendale. For broad context of tribal sovereignty over non-Indian land within Indian country, see CoHEN's HANDBOOK, supra note 24, §6.02(2)(b); see also Philip P. Frickey, A Common Law for Our Age of Colonialism: The Judicial Divestiture of Indian Tribal Authority over Nonmembers, 109 YALE L.J. 1 (1999) (characterizing Montana and Brendale as part of an incoherent, even "chaotic," id. at 43-44, line of cases); David H. Getches, Conquering the Cultural Frontier: The New Subjectivism of the Supreme Court in Indian Law, 84 CALIF. L. REV. 1573 (1996) (criticizing both Montana and Brendale as being part of a trend of overly subjective interpretations of tribal sovereignty by the Supreme Court); Judith V. Royster, The Legacy of Allotment, 27 ARIZ. ST. L.J. 1,61 (1995) (analyzing the cases in light of federal allotment law and policy). Royster states, "With each succeeding decision, the Court becomes more adamant about furthering the allotment policy and less amenable to protecting, or even perceiving, tribal interests." Id.

34. The contours of this assertion cannot be adequately explored by this Article, but for a more nuanced analysis, see Rebecca Tsosie, Tribal Environmental Policy in an Era of SelfDetermination: The Role of Ethics, Economics, and Traditional Ecological Knowledge, 21 VT. L. REV. 225, 272-87 (1996) (providing a thorough account of indigenous land ethics). Tsosie expands upon another scholar's assertion that tribes' traditional world views include, among other important aspects, "a concept of reciprocity and balance that extends to relationships among humans, including future generations, and between humans and the natural world." Id. at 276 (drawing from Ronald L. Trosper, Traditional American Indian Economic Policy, 19 AM. INDIAN CULTURE \& RES. J. 65 (1995)). She goes on to explain, "The interrelationship of people and land, combined with the deeply rooted ethics of reciprocity and balance, lead to a long-term view of ecological stability or, in contemporary terms, a/concern with 'sustainability."' Id. at 285 (citations omitted).

35. See Nat'l WILdLIfe Fed'N, The New Energy Future in Indian Country: Confronting Climate Change, CREATING Jobs, AND CONSERVING NATURE 15 (2010) (detailing such jobs). 
basic principles of justice as fairness to the injustice evident among people devoid of life sustainable energy." ${ }^{36}$ In 2000, the United States Census gathered information showing that over 5500 tribal housing units lack access to any fuel that would provide heat. ${ }^{37}$ The Department of Energy reported that in 1990, one in seven households (about 16,000 in total) on tribal lands lacked access to electricity or other arrangements that would provide electricity at no cost. ${ }^{38}$ This rate is ten times the national average. ${ }^{39}$ Recognizing this problem, the EIA report in 2000 identified thirty-four reservations, pueblos, and Tribal Jurisdiction Statistical Areas with high incidences of households without electricity and projected the availability of and the costs for solar, wind, biomass, and geothermal options. ${ }^{40}$ Any of these options would have to take the form of distributed generation - that is, small-scale production facilities located very close to the households needing service - to reach the underserved communities on tribal lands. Large, concentrated energygenerating facilities on tribal lands would not necessarily meet their needs. Of the 16,000 households counted by the Census to be without electricity in 1990, over 75\% lived on the Navajo Reservation in Arizona and New Mexico, which actually has generation and transmission facilities within reservation boundaries. ${ }^{41}$ On the Navajo Reservation and elsewhere, the presence of more generating facilities could help bring energy to underserved and remote areas and advance the agenda of the energy justice movement.

Native Americans on tribal lands also expend a larger portion of their financial resources on electricity than the national average. In 1990, the average tribal household spent twice as much for electricity when measured by a percentage of income (4\% versus $2 \%)^{42}$ Across the country, the $10 \%$ of households spending the highest percentage of their incomes on electric costs spent an average of $9 \%$ of their income for such costs; the top decile of tribal households spent an average of $20 \%$ of their

36. Lakshman Guruswamy, Energy Justice and Sustainable Development, 21 CoLo. J. INT'L ENVTL. L. \& POL'Y 231, 233 (2010); see also Lakshman Guruswamy, Energy Justice, in Climate Change: A Reader 944 (William H. Rodgers, Jr. et al. eds., 2011); Hari M. Osofsky, Energy Justice (Mar. 2011) (unpublished manuscript) (on file with author).

37. U.S. CENSUS BUREAU, CHARACTERISTICS OF AMERICAN INDIANS AND ALASKA NATIVES BY TRIBE AND LANGUAGE: 2000, at 110 tbl.16 (2003).

38. U.S. ENERGY INFO. ADMIN., supra note 2, at 3-4.

39. Id. app. B, tbl.B.1.A (showing a rate of $1.4 \%$ for all U.S. households and a rate of $14.2 \%$ for households on tribal lands).

40. Id. at 27 tbl.5 (measuring costs for tribal lands ranging in size from the 239-person Iowa TJSA to the 123,944-person Navajo Reservation, in 1990 population figures).

41. Id. at 4 .

42. Id. at 4 fig. 2 . 
incomes. ${ }^{43}$ With respect to natural gas costs as a percentage of income, the highest-paying decile of tribal households spent $15 \%$ of their incomes on natural gas, while the national average across all deciles was a mere $2 \%{ }^{44}$ Renewable energy, if controlled directly by tribes and their members, could reduce costs for those Native Americans who live on reservations.

Recognizing the potential, and driven by the concerns described above, many tribes have begun to explore renewable energy development. Yet tribes have often been stalled in developing projects by cumbersome federal review requirements and limited financial resources, among other factors. With the recent passage of the ITEDSA, Congress has attempted to help tribes more easily navigate this process, although as the next Part will discuss, the Act has not yet met this goal.

\section{The UNFUlFILlED PROMISE OF ITEDSA}

In 2005, Congress passed the ITEDSA, which increases federal support of tribal energy projects and provides a mechanism within which tribes may regulate and develop their energy resources without constant consultation with the federal government. ${ }^{45}$ Although the act itself does not define "energy resources," regulations enacted in 2008 define the term to include a wide range of both renewable and nonrenewable resources. ${ }^{46}$ This Article solely concerns itself with ITEDSA's applicability to renewable resources.

As written, the law affects tribes' ability to develop renewable energy in two primary ways. First, it provides for public support of certain development activities. Two offices created after ITEDSA handle its implementation and help to encourage tribal energy development: the Division of Indian Energy Policy Development within the Indian Energy and Economic Development Office of the Department of the Interior, and the Office of Indian Energy Policy and Programs in the Department of Energy. ${ }^{47}$ ITEDSA also requires or allows, as applicable, the Department of the Interior and the Department of Energy to offer grants,

43. Id.

44. Id. app. B, tbl.B.2.A.

45. 25 U.S.C. $\S \S 3501-3506(2006)$.

46. "Energy resources means both renewable and nonrenewable energy sources, including, but not limited to, natural gas, oil, uranium, coal, nuclear, wind, solar, geothermal, biomass, and hydrologic resources." 25 C.F.R. $\$ 224.30$ (2012).

47. Office of Indian Energy Policy and Programs: Mission, U.S. DeP'T OF ENERGY, http://www.energy.gov/indianenergy/mission (last visited Feb. 17, 2013); Division of Energy Policy Development, U.S. DEP'T OF THE INTERIOR: INDIAN AFFAIRS, http://www.bia.gov/WhoWe Are/AS-LA/IEED/DEPD/index.htm (last visited Feb. 2, 2013). 
technical assistance, low-interest loans, and loan guarantees to tribes. ${ }^{48}$ Federal grants may be used for technical assistance; energy conservation programs; studies relating to acquisition of energy supplies, services, and facilities; planning, construction, development, operation, maintenance, and improvement of tribal electrical generation, transmission, and distribution; the development of a tribal energy resource inventory; and other feasibility studies. ${ }^{49}$ The statute does not specify the amount of funding required to be provided for any of these activities.

Second, and potentially more significantly, ITEDSA expressly authorizes tribes that meet certain criteria to enter into contracts and create rights of way for renewable energy projects. ${ }^{50}$ More specifically, it allows tribes to enter into leases or business agreements for energy resource development on tribal land without approval by the Secretary of the Interior (Secretary) as long as the lease or business agreement is executed pursuant to a tribal energy resource agreement (TERA), the term does not exceed thirty years, and the tribe has entered into a TERA with the Secretary. ${ }^{51}$ It also allows tribes to grant rights of way over tribal land for electric transmission or distribution lines without approval by the Secretary if the right of way is executed in accordance with a TERA; the term does not exceed thirty years; the line serves an electric generation, transmission, or distribution facility on tribal land or a facility on tribal land that possesses or refines energy resources developed on tribal land; and the tribe has entered into a TERA with the Secretary. ${ }^{52}$. When a TERA exists, the federal government disclaims liability for any losses resulting from agreements entered into pursuant to the TERA, placing all responsibilities for such losses on the tribes. ${ }^{53}$

ITEDSA enhances tribes' ability to take actions without the approval of the Secretary, which reduces the time spent obtaining federal approvals and undergoing federal review. Under pre-ITEDSA protocols, tribes had to receive approval from the Secretary to engage in activities

48. 25 U.S.C. $\$ 3502$.

49. Id. $\S \S 3502-3503$.

50. Id. $\S 3504$. For a summary of the history of federal laws dealing with tribal selfdetermination including ITEDSA, see generally Judith V. Royster, Practical Sovereignty, Political Sovereignty, and the Indian Tribal Energy Development and Self-Determination Act, 12 LEWIS \& CLARK L. REV. 1065 (2008).

51. 25 U.S.C. $\$ 3504(a)$.

52. Id. $\S 3504(\mathrm{~b})$.

53. Id. $\S 3504(\mathrm{e})(6)(\mathrm{D})$ ("[T]he United States shall not be liable to any party (including any Indian tribe) for any negotiated term of, or any loss resulting from the negotiated terms of, a lease, business agreement, or right-of-way executed pursuant to and in accordance with a [TERA]."). 
such as leasing land for renewable energy infrastructure development. ${ }^{54}$ Modifications and cancellations of such activities also required Secretarial approval. ITEDSA allows for tribes, in effect, to be "preapproved" for activities covered by ITEDSA, which reduces the time spent petitioning and waiting for Secretarial approval..$^{55}$

Tribes may also save time by using ITEDSA to avoid having to comply with the National Environmental Policy Act (NEPA). ${ }^{56}$ NEPA requires that for "major Federal actions significantly affecting the quality of the human environment," a lengthy study called an environmental impact statement document the environmental impact of the action, its adverse environmental effects, and any alternatives that could reduce any adverse effects. ${ }^{57}$ For an energy infrastructure project overseen by a federal agency, an environmental impact statement might include information about the effects of the construction on flora and fauna, wind patterns, or historic artifacts. Environmental impact statements are notoriously time-consuming and expensive to assemble and often fail to result in any substantive changes to the action under review, because NEPA merely requires the preparation of the statement and does not mandate any substantive results. The Secretary's entering into the TERA is subject to NEPA, with the NEPA review period running concurrently with the public comment period for the TERA. ${ }^{58}$ However, the NEPA process is avoided once a tribe enters into a TERA, because without the Secretary's involvement in the decisions covered by a TERA, the "federal action" trigger fails to be activated. The time and money saved results, in theory, in a greater likelihood that an energy project might be undertaken.

Finalizing a TERA with the Secretary, however, is itself a timeconsuming process for tribes. The Secretary has 270 days to review a proposed TERA and is only required to approve one if the tribe has demonstrated that it has the capacity to regulate the development of tribal energy resources and if the TERA includes certain provisions. ${ }^{59}$ For example, the TERA must provide a process for identifying and evaluating significant environmental effects and for identifying mitigation measures if needed; incorporate a public input phase; and

54. See Judith V. Royster, Tribal Energy Development: Renewables and the Problem of the Current Statutory Structures, 31 STAN. ENVTL. L.J. 91, 112-17 (2012) (discussing the disadvantages of the existing statutes for renewable energy development).

55. 25 U.S.C. $\S 3504(\mathrm{e})$.

56. 42 U.S.C. $\S \S 4321-4347(2006)$.

57. 'Id. $\$ 4332(\mathrm{C})-(\mathrm{E})$.

58. 25 C.F.R. $\$ 224.70(2012)$.

59. Id. $\S \S 224.72, .74$. 
allow for the Secretary's periodic review, evaluation, and feedback. ${ }^{60}$ In addition, it must address how leases, business agreements, or rights of way with the tribes will meet environmental laws, provide for public notification, establish a consultation process with the states, allow for the Secretary's nullification of such agreements under certain circumstances, and become effective only when a copy is delivered to the Secretary, among other things. ${ }^{61}$ The statute gives the Secretary the power to suspend leases, business agreements, or rights of way, or rescind approval of a TERA, if she determines that the tribe is not complying with the TERA. ${ }^{62}$

As several scholars have noted, ITEDSA is among a new wave of federal statutes that pushes tribes toward self-governance, treating the agreements between tribes and the federal government more like treaties between sovereign nations than the top-down, paternalistic statutes of yesteryear. ${ }^{63}$ Even with self-governance as a goal, however, the number of requirements and extent of the TERA process have proven to be so cumbersome, and the disclaimer of all federal liability so daunting, that as of mid-2011 no tribe had successfully negotiated a TERA with the Secretary. Thus while ITEDSA has an ambitious title and important aims, in practice it has changed little.

\section{Remaining Challenges In DeVeloping Renewable EnERGY ON TRIBAL LANDS}

Unfortunately, ITEDSA has failed to spur tribe-controlled renewable energy development on tribal lands. Furthermore, additional challenges remain even as the need to address tribes' unique obstacles during the renewable energy development process have become clear. These obstacles include insufficient public support, inability to fully utilize the same financial incentives for renewable energy as private investors, and remote location far from existing regional transmission lines. ${ }^{64}$ Each will be discussed in turn.

Tribes often lack enough readily available capital to study and plan multimillion dollar renewable energy projects, much less construct them. ${ }^{65}$ Typically, development involves six phases: first, a market

60. Id. $\$ 224.63$.

61. Id.

62. 25 U.S.C. $\S 3504(\mathrm{e}) ; 25$ C.F.R. $\S \S 224.10-.185$.

63. See, e.g., Alex Tallchief Skibine, Indian Gaming and Cooperative Federalism, 42 ARIZ. ST. L.J. 253, 285-87 (2010); Royster, supra note 50, at 1080-82.

64. NAT'L WILDLIFE FED'N, supra note 35, at 16 (summarizing these obstacles).

65. Because of their unique legal status, tribal members and tribal corporations face numerous challenges accessing capital and maximizing profitability beyond the renewable energy 
analysis; second, a scoping analysis to determine the viability of the project; third, load and transmission studies leading to a preliminary engineering design; fourth, legal and financial commitments are obtained; fifth, construction and commissioning of the project; and sixth, the project begins operating and ongoing maintenance begins. ${ }^{66}$ Each of these phases can be very expensive, especially for those communities without trained technical experts who could assist with the evaluation of alternatives.

The ability of tribes to even begin the process of developing renewable energy often depends on outside financial support. A range of federal agencies, from the Department of Energy to the United States Environmental Protection Agency, offer grants for strategic planning, analysis, business development, job training, and construction. ${ }^{67}$ Between 2002 and 2010, for example, the Department of Energy's Tribal Energy Program disbursed $\$ 30.4$ million in support of feasibility studies or construction of 129 tribal projects. ${ }^{68}$ In addition, the United States Department of Agriculture, the Bureau of Indian Affairs, and the United States Department of Housing and Urban Development offer a variety of low-interest loans and loan guaranty programs. ${ }^{69}$ The American Recovery and Reinvestment Act pumped millions more into renewable energy programs, with tribal set-asides. ${ }^{70}$ Still, with a single solar installation alone costing several million dollars, these federal programs cannot possibly offset all costs. It is not clear how many of the 565 federally recognized tribes are currently interested in pursuing renewable energy projects, but significantly more money must be set aside for tribal

context. For recent scholarship describing these barriers, see two related articles by Professor Gavin Clarkson: Accredited Indians: Increasing the Flow of Private Equity into Indian Country as a Domestic Emerging Market, 80 U. CoLo. L. REv. 285 (2009), and Wall Street Indians: Information Asymmetry and Barriers to Tribal Capital Market Access, 12 LEWIS \& CLARK L. REV. 943 (2008).

66. DOUGlas C. MaCCOURT, RENEWABle ENERGy DeVELOPMENT IN INDIAN COUNTRY: A HANDBOOK FOR TRIBES 9-10 (2010), available at http://www.nrel.gov/docs/fy 10osti/48078.pdf.

67. Types of Financial Assistance, OFFICE OF ENERGY EFFICIENCY \& RENEWABLE ENERGY, U.S. DEP'T OF ENERGY (May 16, 2012), http://wwwl .eere.energy.gov/financing/types_assistance. html; Grant Opportunities, U.S. ENVTL. PROT. AGENCY (Dec. 11, 2012), http://www.epa.gov/epa home/grants.htm.

68. Pierce, supra note 18.

69. See, e.g., Indian Loan Guaranty Progtam, U.S. DeP'T OF THE INTERIoR: INDIAN AFFAIRS (Feb. 15, 2013), http://www.bia.gov/WhoWeAre/AS-IA/IEED/DCI/index.htm; Grants and Loans, U.S. DEP'T OF AGRIC., http://www.usda.gov/wps/portal/usda/usdahome?navid= GRANTS_LOANS (last visited Feb. 18, 2013); Indian Housing Block Grant Program, U.S. DEP'T OF HOUSING \& URBAN DEV., http://portal.hud.gov/hudportal/HUD?src=/program_offices/public indian_housing/ih/grants/ihbg (last visited Feb. 18, 2013).

70. See Pierce, supra note 18. 
development projects across the country to ensure that the tribes who do want help can get enough.

Public financial support is more important for tribes than for other groups because tribes cannot take advantage of the same financial incentives for renewable energy as taxable private entities. Private investment in renewable energy has been spurred, in large part, by incentives such as tax credits that offset the costs of projects. The federal production tax credit, for example, gives a tax credit of 1.5 cents per each kilowatt-hour to the producer of electricity produced from wind, biomass, geothermal, solar, and other sources." The federal energy investment tax credit provides a tax credit of up to $30 \%$ of certain costs for qualifying wind, solar, fuel cell, and other projects. ${ }^{72}$ Tribes, however, do not pay federal taxes to which such credits would apply, and the credits are not transferable from tribes to taxable entities.

The inability to take advantage of tax credits and other incentives forces tribes eager to build renewable energy projects to make hard choices. Instead of entering into joint venture relationships, in which a tribe and nontribal entity co-own infrastructure, tribes and nontribal entities more commonly enter into leasing arrangements, in which tribes lease their land and the nontribal entities build and own the infrastructure. ${ }^{73}$ As landlords, tribes must often pay state taxes on leasing income, which reduces the value of the lease. Moreover, lease terms may be longer than would otherwise be preferable so that the nontribal entity can take advantage of tax credits or other incentives. ${ }^{74}$ Leases may also hinder tribes' efforts to negotiate the transmission of energy to their own people, if the nontribal entity owning the infrastructure anticipates higher profits from nontribal end users. Making renewable energy-related tax credits transferable, as some have suggested, would help to make partnering with non-Indian taxable entities more lucrative for tribes.

Finally, neither ITEDSA nor any other law clearly addresses the effects of energy sprawl on or beyond tribal lands. Energy sprawl, a term coined by the Nature Conservancy in 2009 , refers to the amount of land occupied by energy production and the related impacts on ecosystems, habitat, and wildlife activity. ${ }^{75}$ The Nature Conservancy measured the land-use intensity of different methods of energy production and found

71. 26 U.S.C. $\S 45(2006)$.

72. Id. $\S 48$.

73. Mark Shahinian, Note, The Tax Man Cometh Not: How the Non-Transferability of Tax Credits Harms Indian Tribes, 32 AM. INDIAN L. REv. 267, 281 (2007-2008).

74. See id. at 279-81.

75. Robert I. McDonald et al., Energy Sprawl or Energy Efficiency: Climate Policy Impacts on Natural Habitat for the United States of America, 4 PLOS ONE 1, 1 (2009). 
that even the "greenest" of technologies disturbs land, both directly and indirectly. ${ }^{76}$ For example, solar photovoltaic energy is estimated to disturb nearly thirty-seven square kilometers per terawatt-hour produced annually, while wind development is estimated to disturb seventy-two square kilometers per terawatt-hour." Biomass, meanwhile, is estimated to disturb a startling 543.4 kilometers per terawatt-hour annually, owing to the large quantities of plant or crop material needed to produce each unit of energy.

The potential for energy sprawl may actually be more significant on and near tribal lands than elsewhere. Many tribal lands are vast territories with populations living far less densely than in urban areas, so unless distributed generation is used to deploy small-scale renewable energy to smaller groups of end users, infrastructure within tribal lands must be built across long distances. For those end users off of tribal lands, to whom sales may be part of the economic calculus of the project, transmission of energy from a tribal generating facility may also be space-consuming. Even if an energy project is situated at or near a border, getting energy from a tribal energy project to non-Indian end users could require extensive (not to mention expensive, at perhaps $\$ 10,000$ a linear mile) transmission and distribution infrastructure. ${ }^{79}$

Further compounding the energy sprawl problem, as noted above, environmental and land use controls on tribal lands may be less rigorous than in other areas. As a result, the impact of the construction of renewable energy infrastructure may go understudied, and less care may be taken in its siting. Even ITEDSA, which attempts to facilitate renewable energy projects on tribal lands, could have the unintended consequence of allowing for siting to occur in a detrimental fashion, by advancing a mechanism for tribes to avoid complying with NEPA. Although NEPA does not require the least environmentally disruptive alternative, it at least requires the documentation and consideration of environmental impacts. ITEDSA requires tribes seeking to enter into a TERA to propose a process for environmental review, but it is not clear whether this review would have to include impacts of infrastructure development on the land and ecosystems. ${ }^{80}$

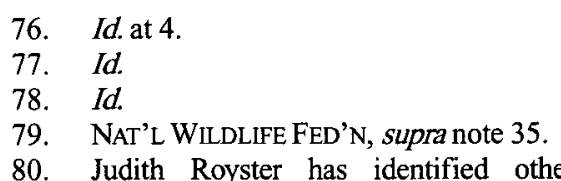

80. Judith Royster has identified other concerns with ITEDSA's approach to environmental review, including its public review requirements, which she feels "conflict sharply with tribal self-governance." Royster, supra note 50, at 1086, 1090-95. 
Moving the engines of production closer to their end users is one way to reduce energy sprawl. ${ }^{81}$ But for tribes with limited resources to invest in renewable energy, small-scale production serving small groups seems unlikely to occur. So for the large-scale projects anticipated by ITEDSA, siting guidelines are needed to minimize environmental impacts.

\section{CONCLUSION}

As the United States pushes for more renewable energy infrastructure, tribal lands rich in opportunities for siting renewable projects must be seen as part of the solution. The current legal framework for using tribal land for renewable energy projects fails, however, to address adequately the needs of tribes and the environment. As a result, some of the land most suitable for renewable energy projects continues to lie dormant, while some land being developed for energy projects may be in jeopardy of long-term damage.

Where do we go from here? As a starting point, policymakers should fully fund or expand existing programs giving public support to tribes for renewable energy projects and make it easier for tribes and their members to obtain grants, technical assistance, low-interest loans, and loan guarantees. The expansion of these financial incentives depends on political will and budget priorities, but a factor cutting in favor of expansion is that even moderate public subsidies of renewable energy generate significant tribal and nontribal private investment. ${ }^{82}$ Along the same lines, Congress and state legislatures should make renewable energy tax credits fully transferrable by tribes to taxable entities willing to pay for them. ${ }^{83}$

As a second step, the portions of ITEDSA that relate to tribal energy resource agreements should be reconsidered and revised. The revision process must fully involve diverse tribes, and tribal sovereignty must underlie all decisions. ${ }^{84}$ Several key areas call for revisions. The

81. See, e.g., Bronin, supra note 6 , at 573-75 (recommending small-scale microgrids that produce energy to help reduce energy sprawl).

82. See Elizabeth Ann Kronk, Alternative Energy Development in Indian Country: Lighting the Way for the Seventh Generation, 46 IDAHO L. REv. 449, 467-70 (2010) (describing barriers to renewable energy projects on tribal land and focusing on projects in the Navajo Nation, Kumeyaay Tribe, and Blackfeet Nation).

83. See Shahinian, supra note 73 , at 282-90.

84. See generally James M. Grijalva, Control and Accountability: The Twin Dimensions of Tribal Sovereignty Necessary To Achieve Environmental Justice for Native America, in TRIBES, LAND, AND THE ENVIRONMENT, supra note * (analyzing recent attempts to adapt federal public participation regulations to the tribal context and arguing that true environmental justice is possible only when tribal sovereignty underlies the adapted environmental review processes). 
time limit on the terms of lease and business agreements-currently thirty years - might be lengthened or abandoned. The number of days the Secretary may take to review a proposed TERA may be shortened from the current figure, 270. Perhaps most significantly, tribes and policymakers could consider how to better allocate liability for losses related to agreements tribes make under a TERA. A careful review of ITEDSA's TERA provisions, and reforms approved by both policymakers and tribes, would encourage tribes to take advantage of the selfdetermination powers granted by ITEDSA.

Finally, tribes' obligations with regard to their impact on the natural environment should be clarified in ITEDSA and other statutes. As noted above, although ITEDSA mandates an environmental review for projects subject to a TERA, the statute fails to delineate tribes' specific obligations. It also omits any siting guidelines that might reduce the negative effects of energy sprawl. Even if, in consultation with tribes, Congress changed ITEDSA to include more specific environmental review and siting procedures, such procedures would likely only apply to projects built pursuant to a TERA. Accordingly, other legislation must be drafted to account for these important priorities outside the TERA context.

This Article, which has focused on identifying current issues regarding siting renewable energy on tribal land, concludes with these broad suggestions, while leaving the articulation of specific solutions to others. A comprehensive solution to overhaul the tax, jurisdictional, and land use laws to facilitate tribes' use of renewable energy cannot come too soon for these important projects. 
